\title{
Application of Consumer Clustering Mining Data Mining in Household with Fuzzy Multi Criteria Decision Making (FMCDM)
}

\author{
Muhammad Anshari ${ }^{[1]}$, I Putu Suryadharma ${ }^{[2]}$, and Nyoman Putra Sastra ${ }^{[3]}$ \\ [1][2] Department of Electrical and Computer Engineering, Post Graduate Program, Udayana University, \\ [3] Department of Electrical and Computer Engineering, Udayana University \\ Email: muhammad.anshari16@gmail.com
}

\begin{abstract}
This study aims to classify consumers in the selection of houses using Fuzzy Multi Criteria Decision Making (FMCDM) method based on data mining. Alternative houses provided there are four of the minimalist houses, contemporary modern homes, classical houses, and traditional ethnic houses. To generate these choices, there are five criteria: price criteria, home/type criteria, interior criteria, exterior criteria, and home environmental criteria. The results of this study can help system users in determining the choice of home type based on the user's tastes of the criteria available and also can help the investors and contractors in building houses, villas, hotels, and housing of the criteria.
\end{abstract}

Keywords: Home Architecture, Fuzzy Multi Criteria Decision Making, minimalist house, contemporary modern house, classic house, traditional ethnic house

\section{PRELIMINARY}

The concept of a decision support program (Decision Support System) is currently growing rapidly. Many methods are used to assist in making decisions, especially those based on several alternatives. Decision makers should consider alternatives that are factors that support successful decision making resulting in optimal decisions[1].

One method that can be used is the Fuzzy MultiCriteria Decision Making (FMCDM) method. This method is developed to help decision makers in making decisions on some alternative decision to get an accurate and optimal decision[1].

Every human being needs a dwelling called a house. Residential home is something that is important in human life. This is because the house is a shelter used by humans to shelter against nature and surroundings and to do activities with family. Because of the very importance of home for human life, the people who occupy it, want the house is comfortable in accordance with the coveted.

From this desire appears the architecture of the house. In general, one's home architecture, usually tailored to the taste of the owner of the house. In fact, the architecture of the house cannot be determined easily because the architecture of a building is determined not only by taste but the architecture of the house must also be in harmony with the surrounding environment, materials used quality and many more considerations to have a good and ideal home architecture.

The purpose of this research is to apply data mining in decision support system of home architecture selection using Fuzzy Multi Criteria Decision Making (FMCDM) method to conduct selection of home architecture

\section{LITERATURE REVIEW}

\section{A. Home Architecture}

Architecture is the art and science in designing buildings. In a broader sense, architecture includes designing and building the entire built environment, ranging from the macro level of planning to the micro level of the building design and interior design. Architecture is born out of the dynamics between needs (the need for conducive environmental conditions, security, etc.) and the way (available building materials and construction technologies). Prehistoric and primitive architecture is the first stage of this dynamic. Then humans become more advanced and knowledge begins to form through oral traditions and practices, architecture evolves into skills. At this stage there is a process of testing, improvisation, or imitation so that it becomes a successful outcome.[2], [3]

While home is one of the basic human needs. Home can be defined as: "The space where people live and perform activities free of life from physical and psychological disorders". Every human being needs a place to live and spend time with loved ones, that's why home is a basic human need. Like other basic needs, the fulfillment of the needs of the house as a place of residence must and absolutely to be met, the house that currently has a variety of models and shapes because it is tailored to the needs of its inhabitants. So from the conclusion above the architecture of the house is the art and science of designing an ideal house or dwelling in an environment that becomes a decent family residence, in terms of social life, health, and harmony of home or residence[3], [4]. Home Architecture Criteria in general the architecture of the house is a thing to be considered in building a house. There are several criteria in determining the architecture of the house: 
a. Price, is the main thing considered by the user in determining the architecture of the house, because the price is an important thing in building a dwelling. Users will build the occupancy in accordance with the user's own capabilities.

b. Type of house, is the land area and size of the building to be built.

c. Interior of the house is a spatial / design arrangement and design interior spaces in the house.

d. The exterior of the house is the first part that will be seen by people (space outside the building) therefore the exterior of the house is a criterion that is very influential in the selection of home architecture.

e. Environment, is a matter to consider also in determining the architecture of the house, whether the user is looking for a quiet and quiet rural environment (rice fields) or in a crowded urban environment.

\section{B. Fuzzy Multi Criteria Decision Making}

Fuzzy multi-criteria decision making is one method that can help decision makers in making decisions on some alternative decisions to be taken with some criteria that will be considered. In relation to the decision making of several alternatives with many criteria, as well as the information provided is qualitative, then in this study will try to use the method of fuzzy multi-criteria decision making[1], [5]

\section{RESEARCH METHODOLOGY}

In the process of choosing home architecture that is done by using MCDM fuzzy, we need criteria, weight of interest of each criterion and rating of alternative match against the criteria to do the calculation so that will get the best alternative. In this case the best alternative referred to is the right house architecture to be occupied.

Stages of the research process begins by grouping the types of houses as an alternative choice.

Table 1 Alternative

\begin{tabular}{|c|l|}
\hline Alternative & \multicolumn{1}{|c|}{ Information } \\
\hline A1 & Minimalist house \\
\hline A2 & Modern House (Contemporary) \\
\hline A3 & Classic House \\
\hline A4 & Ethnic House (traditional) \\
\hline
\end{tabular}

In table 1 made alternative home choices, there are 4 choices of minimalist homes, contemporary modern homes, classical houses, and traditional ethnic houses.

The next process is the process of determining the criteria to support the process of determining the type of house. The criteria can be seen in table 2 .

Table 2 Criteria

\begin{tabular}{|c|l|}
\hline Criteria & \multicolumn{1}{|c|}{ Information } \\
\hline $\mathrm{C} 1$ & House Price \\
\hline $\mathrm{C} 2$ & Home Type \\
\hline
\end{tabular}

\begin{tabular}{|l|l|}
\hline C3 & Interior \\
\hline C4 & Exterior \\
\hline C5 & Environment \\
\hline
\end{tabular}

In table 2 there are five criteria, namely price criteria, house type, interior, exterior, and environmental criteria.

The hierarchical structure of the problem can be seen in figure 1.

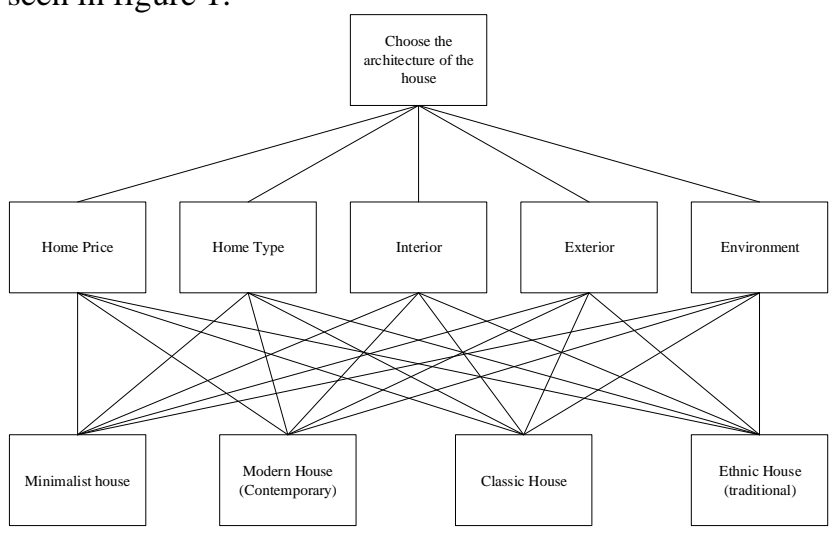

Figure 1 Hierarchy Structure Issues

In this research, membership function of fuzzy number used is function of fuzzy triangle number, whose membership function has been expressed in the formula below that is:

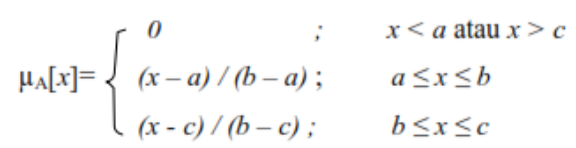

\section{RESUltS AND DisCUSSION}

\section{A. Analysis Phase}

Analysis phase is to determine the weight of interest for each criterion, as shown in the table 3.

Table 3 Rating Of Interest For Each Criterion

\begin{tabular}{|c|c|c|c|c|c|}
\hline Criteria & C1 & C2 & C3 & C4 & C5 \\
\hline Rating of Interest & VH & H & H & VH & VH \\
\hline
\end{tabular}

Information:

$\begin{array}{ll}\text { VH } & : \text { Very high } \\ H & : \text { High } \\ E & : \text { Enough } \\ L & : \text { Low } \\ V L & : \text { Very Low }\end{array}$

In the table above, there are two criteria that are $\mathrm{C} 2$ and $\mathrm{C} 3$ which have a high interest weight $(\mathrm{H})$, and three criteria are $\mathrm{C} 1, \mathrm{C} 4$, and $\mathrm{C} 5$, which have very High importance weight (VH).

Table 4 Rating Match Every Alternative Against Each Criteria

\begin{tabular}{|c|c|c|c|c|c|}
\hline \multirow{2}{*}{ Alternative } & \multicolumn{5}{|c|}{ Match Rating } \\
\cline { 2 - 6 } & C1 & C2 & C3 & C4 & C5 \\
\hline A1 & VG & VG & E & G & E \\
\hline A2 & G & E & VG & G & VG \\
\hline
\end{tabular}




\begin{tabular}{|c|c|c|c|c|c|}
\hline A3 & E & E & G & VG & G \\
\hline A4 & E & G & VG & G & VG \\
\hline
\end{tabular}

\section{Information:}

VG : Very good

G : Good

E : Enough

L : Low

VL : Very Low

Table 4 shows that the alternative match rate (A1) to the criteria $\mathrm{C} 1, \mathrm{~A} 2$ to $\mathrm{C} 2, \mathrm{~A} 2$ to $\mathrm{C} 3, \mathrm{C} 2$, to $\mathrm{C} 3, \mathrm{~A} 4)$ to (C3), (A4) to (C5) has an Excellent match rating (VG).

Good match rating $(\mathrm{G})$ is obtained on the match between the alternatives (A1) to (C4), (A2) to (C1), (A2) to $(\mathrm{C} 4),(\mathrm{A} 3)$ to $(\mathrm{C} 3),(\mathrm{A} 3)$ to $(\mathrm{C} 5),(\mathrm{A} 4)$ to $(\mathrm{C} 2),(\mathrm{A} 4)$ to (C4).

Table 4 also explains that between the alternatives (A1) to the criteria $\mathrm{C} 3, \mathrm{~A} 1$ to $\mathrm{C} 5, \mathrm{~A} 2$ to $\mathrm{C} 2, \mathrm{~A} 3$ to $\mathrm{C} 1, \mathrm{~A} 3$ to $\mathrm{C} 2) \mathrm{To}(\mathrm{C} 1)$ has a moderate fit rating $(\mathrm{E})$.

Table 5 Price Criteria

\begin{tabular}{|c|c|c|c|}
\hline No & Price & Weight & Information \\
\hline 1 & Very cheap & 0 & IDR 0 s/d IDR 250.000.000 \\
\hline 2 & Cheap & 0.25 & $\begin{array}{c}\text { IDR 250.000.000 s/d } \\
\text { IDR 550.000.000 }\end{array}$ \\
\hline 3 & Standard & 0.5 & $\begin{array}{c}\text { IDR 550.000.000 s/d } \\
\text { IDR 750.000.000 }\end{array}$ \\
\hline 4 & Expensive & 0.75 & $\begin{array}{c}\text { IDR 750.000.000 s/d } \\
\text { IDR 2.000.000.000 }\end{array}$ \\
\hline 5 & $\begin{array}{c}\text { Very } \\
\text { expensive }\end{array}$ & 1 & $>$ IDR 2.000.000.000 \\
\hline
\end{tabular}

Table 6 Type / House Criteria

\begin{tabular}{|c|c|c|c|}
\hline No & House Area & Weight & Information \\
\hline 1 & Very narrow & 0 & $50 \mathrm{~m} 2$ \\
\hline 2 & Narrow & 0.25 & $100 \mathrm{~m} 2$ \\
\hline 3 & Enough & 0.5 & $200 \mathrm{~m} 2$ \\
\hline 4 & Large & 0.75 & $500 \mathrm{~m} 2$ \\
\hline 5 & Very wide & 1 & $1000 \mathrm{~m} 2$ \\
\hline
\end{tabular}

Table 7 Interior Criteria

\begin{tabular}{|c|c|c|c|}
\hline No & Interior & Weight & Information \\
\hline 1 & Very simple & 0 & - \\
\hline 2 & Simple & 0.25 & - \\
\hline 3 & Enough & 0.5 & - \\
\hline 4 & Luxury & 0.75 & - \\
\hline 5 & Very Luxury & 1 & - \\
\hline
\end{tabular}

Table 8 Exterior Criteria

\begin{tabular}{|c|c|c|c|}
\hline No & Exterior & Weight & Information \\
\hline 1 & Very simple & 0 & - \\
\hline 2 & Simple & 0.25 & - \\
\hline 3 & Enough & 0.5 & - \\
\hline 4 & Luxury & 0.75 & - \\
\hline 5 & Very Luxury & 1 & - \\
\hline
\end{tabular}

Table 9 Environment Criteria

\begin{tabular}{|c|c|c|c|}
\hline No & Environment & Weight & Information \\
\hline 1 & Very quiet & 0 & $\begin{array}{c}\text { Outback, Near Nature } \\
\text { Tour }\end{array}$ \\
\hline 2 & Quiet & 0.25 & Suburbs / Villages \\
\hline 3 & Enough & 0.5 & Rural \\
\hline
\end{tabular}

(p-issn: 2579-5988, e-issn: 2579-597X)

\begin{tabular}{|l|c|c|c|}
\hline 4 & Crowded & 0.75 & Urban \\
\hline 5 & Very crowded & 1 & City center \\
\hline
\end{tabular}

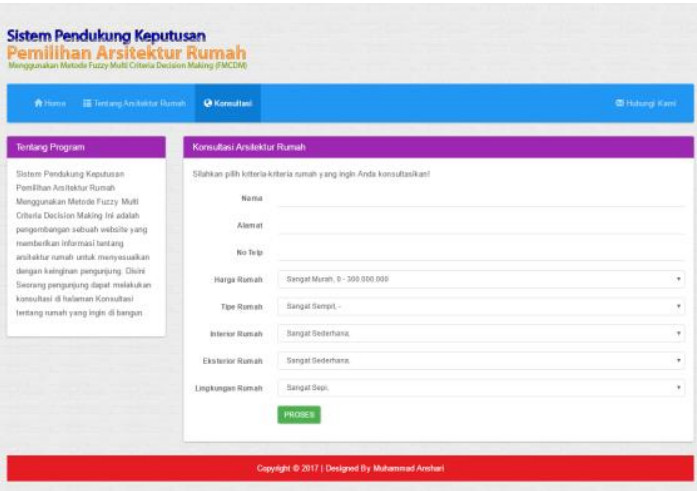

Figure 2 Consultation form

In Figure 2 is a consultation form page for visitors. Visitors are required to fill in the data in the existing column, then select some options based on existing criteria. Then press the process button to see the result.

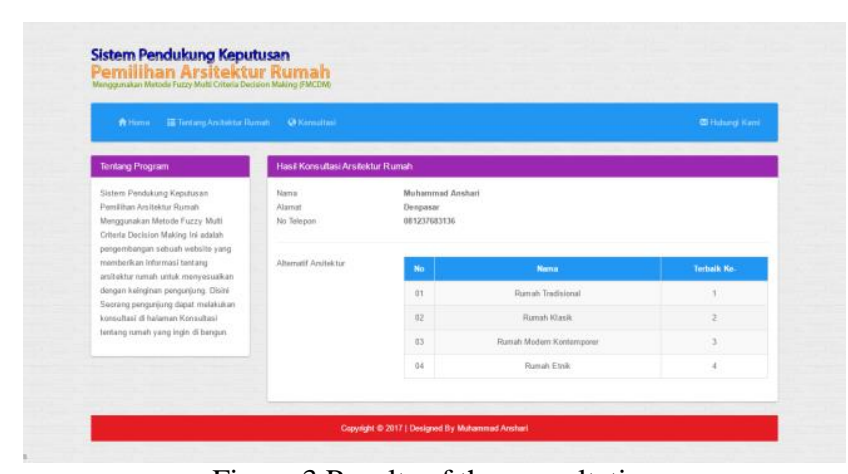

Figure 3 Results of the consultation

Figure 3 shows the results of the house selection consultation process, from several selected criteria resulting in a more viable alternative to traditional houses.

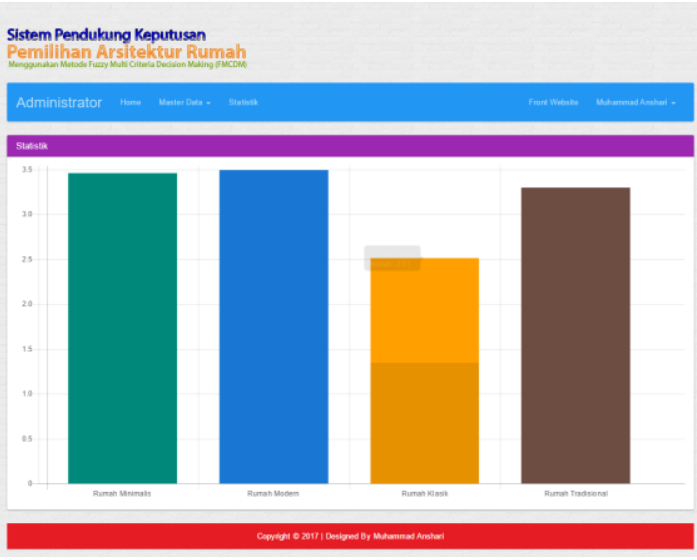

Figure 4 Survey survey statistics

Figure 4 shows the statistics of the entire consultation conducted by all visitors. It can be concluded that the modern house occupies the highest position then 
the minimalist house, then the traditional house, and the last became the last option is the classic house.

\section{CONCLUSIONS}

1. The use of fuzzy multi criteria decision making method (FMCDM) is quite helpful for the process of choosing home architecture for website based visitor system.

2. Based on the results of the consultation process by visitors, the statistic shows (figure 4) minimalist homes and contemporary modern homes still dominate the choice of visitors in the selection of houses based on criteria that exist, while the classical house is most rarely selected.

3. This statistic can be an understanding and reference in building a house for contractors and investors who want to build houses, villas, hotels, housing, based on existing criteria.

\section{REFERENCES}

[1] S. Kusumadewi and I. Guswaludin, "Fuzzy MultiCriteria Decision Making," Media Inform., vol. 3, no. 1, 2009.

[2] . Hartanti; . Rosliana; . Rusmiyati; Andery Prasetyo; . Sukmadewanari; Robby Sobara; Ahmad Kurniawan, "Arsitektur Rumah Masyarakat Dayak Di Desa Pampang Samarinda-Kalimantan Timur," Kalang, no. \#\#issue.vol\#\# 7, \#\#issue.no\#\# 2 (2004): Volume 7 No.2, 2004.

[3] H. M. Kapugu Vicky H. ..Rengkung, Joseph, "Kajian Perubahan Bentuk Arsitektur Denah Rumah Tinggal Kaitan Dengan Sosial Ekonomi Dan Budaya Masyarakat Pemukim Pada Perumahan Karyawan Kantor Gubernur Di Winangun Manado," MEDIA MATRASAIN, no. Vol 9, No 3 (2012), pp. 33-46, 2012.

[4] P. . Salura Antariksa; Fauzy, Bachtiar, "Memahami Relasi Konsep Fungsi, Bentuk Dan Makna Arsitektur Rumah Tinggal Masyarakat Kota Pesisir Utara Di Kawasan Jawa Timur (Kasus Studi Rumah Tinggal Di Kampung Karangturi Dan Kampung Sumber Girang, Lasem)," DIMENSI J. Tek. Arsit., no. Vol 38, No 2 (2011): DECEMBER 2011, pp. 79-88, 2011.

[5] S. Kusumadewi and H. Purnomo, Aplikasi Logika Fuzzy untuk Pendukung Keputusan, 2nd ed. Yogyakarta: Graha Ilmu, 2013. 